\title{
АНАЛІЗ ЕФЕКТИВНОСТІ МЕТОДІВ ТА СТРАТЕГІЙ ПСИХОЛОГІЧНОЇ ДОПОМОГИ ПРИ РОЗЛАДАХ ХАРЧОВОЇ ПОВЕДІНКИ
}

\section{Абсалямова Лариса Миколаӥвна}

\author{
Кандидат психологічних наук, доцент, дочент \\ кафедри практичної психології, Національний \\ педагогічний університет імені Г. С. Сковороди, \\ м. Харків (Украӥна)
}

\begin{abstract}
Анотація. У статті досліджується психологічна допомога при розладах харчової поведінки як підтримуючий процес для постановки пріоритетів та цүілей, а також створення індивідуалізованих планів дї. Підкреслюється, щзо біхевіоральна теорія та когнітивнобіхевіоральна теорія засновані на припущенні, щзо вся поведінка є научуваною, та щзо внутрішні та зовнішні фактори впливають на поведінку особистості. Перевіряється терапевтична ефективність ияих теорій в різних емпіричних дослідженнях. Аналізуються основні положення щзодо того, щуо консультування з проблем харчової поведінки, здійснюване фахівцями, має здатність покращитти втрату ваги, стабілізацію ваги, рівень иукру в крові для людей з діабетом другого типу та ризиками сериево-судинних хвороб. Переконливі емпіричні дані підтверджують ефективність самоспостереження, мотиваційного опитування (зокрема, в поєднанні 3 когнітивно-біхевіоральною терапією), заміну їжі та структуровані плани харчування як стратегії в психологічній допомозі людям з розладами харчової поведінки.
\end{abstract}

Ключові слова: харчова поведінка, психологічна допомога, розлад харчової поведінки, когнітивно-біхевіоральна теорія, когнітивно-біхевіоральна психотерапія, стратегії консультування, самоспостереження, мотиваційне опитування.

Постановка проблеми. Одним із завдань сучасної практичної психології є показати, як консультативні інтервенції у харчову поведінку можуть бути ефективно виміряні та підтверджені. Використання теоретичних засад для інтервенцій є ключовим для розуміння та вимірювання їх ефективності. Гіпотези та рандомізовані контрольовані дослідження (РКД) можуть бути вибудувані навколо теорій, які здійснюють вибір специфічних технік.

У сучасному суспільстві актуалізується проблема порушень харчової поведінки. 3 одного боку, усе більша кількість людей страждає від надмірної маси тіла і переїдання, з ін- 
шого боку, все частіше за обмеження в харчуванні, іноді абсолютно не пов'язані з реальною вагою і формою тіла, набувають характеру пандемії, що захопила весь світ. Доведено, що нав'язливі форми поведінки, пов'язані із споживанням їжі, значно частіше зустрічаються у жінок, особливо в підлітковому i юнацькому віці. Більшість дослідників головну причину подібної ситуації, бачить в експлуатації глянцевими журналами і індустрією моди природного прагнення жінок бути красивими. В той же час, незважаючи на наполегливий тиск соціуму, що примушує молодих людей худнути, далеко не у усіх з них формуються порушення харчової поведінки.

Психологічна допомога при розладах харчової поведінки - це підтримуючий процес для постановки пріоритетів та цілей, а також створення індивідуалізованих планів дії для клієнта, який визнає та підтримує відповідальність за турботу про себе. Фахівціпсихологи часто проводять психологічне консультування $з$ проблем харчування 3 клієнтами для фасилітації поведінкових змін. Для того, щоб праця фахівців була дієвою, фахівці 3 розладів харчової поведінки мають розумітися на наукових основах харчової поведінки людини та дієтології, на різноманітних етнічних та регіональних кулінарних особливостях. Теорії та моделі, валідизовані у сфері дієтології, є орієнтирами, які допомагають практикуючим фахівцям краще зрозуміти внутрішні та зовнішні проблеми клієнта та динамі- ку, що призводить до поведінкових змін. Використання цих орієнтирів забезпечує вибір специфічних стратегій консультування для досягнення цілей консультування.

Порушення харчової поведінки виникають частіше у тому випадку, якщо у родичів відзначалися такого роду розлади, а також розлади настрою (депресія), залежності від психоактивних речовин (особливо алкоголю), а також ожиріння (для нервової булімії). Розвитку порушень харчової поведінки сприяють дезадаптивні умови сімейного виховання, сексуальне насильство, прихильність дієтам членів сім'ї і самого підлітка (у 18 разів вище у тих дівчаток-підлітків, які використовують жорсткі дієтичні програми і в 5 разів вище, при помірних дієтичних обмеженнях в зіставленні з тими підлітками, які дієт не дотримуються). Провокувати розвиток порушень харчової поведінки можуть критичні зауваження відносно маси і форми тіла з боку членів сім'ї і найближчого оточення. Ризик розвитку розладів вище у осіб, що займаються специфічними видами спорту, або професія яких вимагає відповідності жорстким стандартам зовнішності (наприклад, легка атлетика, танцюристи балету, модельний бізнес і ін.). Для людей, що страждають порушенням харчової поведінки, властива знижена самооцінка, перфекціонізм (задоволеність від досягнення дуже високих результатів, невиправдано високі стандарти, інакше - переживання приниження i поразки) як риса характеру. 


\section{Аналіз останніх досліджень та публі-}

кацій. Останніми роками при поясненні причин прояву нервової анорексії або нервової булімії фахівці прибігають до багатостороннього розгляду перспектив ризику. Тобто вони визначають ключові чинники, які ставлять людей перед ризиком таких захворювань. Чим більше таких чинників в даний момент, тим вище ризик розвитку розладу. Серед лідируючих чинників: соціокультурні умови (соціальний i сімейний тиск), психологічні проблеми (когнітивні розлади, дезадаптований стан) і біологічні чинники.

Біхевіоральна теорія та когнітивнобіхевіоральна теорія засновані на припущенні, що вся поведінка є научуваною, та що внутрішні та зовнішні фактори впливають на поведінку особистості $[1,2,3]$. Ці теорії заохочують такі стратегії, як самоспостереження та вирішення проблем, що робить людей більш уважними до внутрішніх та зовнішніх факторів та своїх реакцій на ці фактори. Клієнтів можна навчити низці стратегій для розвитку поведінкових змін: самоспостереження, вирішення проблем, постановка цілей, управління ймовірностями, когнітивне реструктурування, соціальна підтримка, контроль стимулів, стресменеджмент, запобігання загостренням $[1,3]$. У цілому біхевіоральна модель описує поведінкову зміну у вигляді низки стадій і забезпечує теоретичне обгрунтування для підбору стратегій консультування відповідно до різних стадій змін.
Соціально-когнітивна теорія користується характеристикою під назвою «самоефективність» (впевненість у можливості особистості виконати певне завдання), яка впливає на зусилля, які клієнт бажає докласти для досягнення мети [3]. Розвиток навичок та постановка цілей - це стратегії, заохочувані соціально-когнітивною теорією для підвищення самоефективності та наполегливості клієнта у зусиллях, спрямованих на зміну поведінки.

А. Ш. Тхостов у своїй монографії «Психологія тілесності» [4] декларує психосоматичну єдність людини і розглядає нормальну тілесність і патологію тілесності. У його психофізіологічному підході тіло є універсальним зондом і повинно усвідомлюватися лише на рівні своїх меж, що розділяють світ і суб'єкта. Воно повністю підпорядковане суб'єктові. В стані нормального функціонування тіло ніби «прозоре», воно не усвідомлюється. У разі соматичного захворювання тіло стає власним об'єктом свідомості. Також тіло стає власним об'єктом свідомості при освоєнні нових рухів, при нездатності виконати якінебудь дії, тобто при зіткненні з межами своїх можливостей. Тіло - це одночасно Я і Не-Я, але вмістище істинного Я, через яке Я здатне виражати свою суть [4, с. 121].

Використання теорій та моделей поведінкових змін при описі та впровадженні програм та протоколів психологічної допомоги при розладах харчової поведінки дає можли- 
вість практикуючим фахівцям застосовувати перевірені стратегії для покращення ефективності консультування. Теорії зміни поведінки забезпечують теоретичне обгрунтування для індивідуалізованих інтервенцій з психологічної допомоги людям з розладами харчової поведінки, щоб забезпечити потреби клієнтів, які можуть виявляти різний рівень мотивованості, довіри, підтримки соціального оточення та особистих навичок.

Постановка завдання. На основі викладеного можна сформулювати завдання дослідження, яке полягає в теоретичному обгрунтуванні та емпіричній перевірці ефективності різних методів надання психологічної допомоги при розладах харчової поведінки.

Виклад основного матеріалу дослідження. Для того, щоб з'ясувати, наскільки різні методи психологічного консультування $\epsilon$ ефективними для клієнтів з розладами харчової поведінки, ми проаналізували матеріали емпіричних досліджень (переважно зарубіжних [5-16]), в яких надійно та валідно підтверджувалися переваги та/або недоліки певних методів та підходів.

Біхевіоральна теорія та когнітивнобіхевіоральна теорія - це найстаріші та найбільш перевірені теорії зміни поведінки, які застосовуються в психологічному консультуванні з проблем порушень харчової поведінки. Ці дві теорії забезпечують теоретичну основу для більшості структурованих дієт, комплексів фізичних вправ та програм поведінкової терапії. Ці дві теорії припускають, що поведінка $\epsilon$ научуваною і ії можна перевчити, використовуючи низку когнітивних та поведінкових стратегій, яким навчаються клієнти для використання у своєму житті. Когнітивнобіхевіоральна терапія фокусується як на зовнішніх факторах, наприклад стимулах оточення, так і на внутрішніх факторах, наприклад на думках і мисленні. Фахівці зазвичай застосовують стратегії, що впливають як на внутрішні, так і на зовнішні фактори, аби зруйнувати небажані харчові поведінкові патерни. Численні дослідження доводять, що когнітивнобіхевіоральна теорія $є$ корисною у фасилітації змін бажаних харчових звичок (наприклад, зменшене споживання жирів, збільшене споживання фруктів та овочів), ваги та ризиків виникнення серцево-судинних і діабетичних захворювань.

Зокрема, вражаючими є результати, отримані в дослідженнях тривалістю від 6 до 12 місяців 3 використанням когнітивнобіхевіоральної терапії з діабетом другого типу. Дві дослідницькі групи, у першу з яких входило 5145 досліджуваних [16], а в другу 58 (рандомізовані контрольовані дослідження) [11], застосовували інтенсивну програму зміни способу життя та показали значні покращення в рівні цукру крові, гліколізованого гемоглобіну та ваги $[11,16]$. В іншому дослідженні були показані вражаючі результати когнітивно-біхевіоральної терапії в попередженні чи відстрочуванні початку діабету. До- 
слідники виявили значуще зниження виникнення діабету другого типу на 58\% протягом чотирирічного періоду [12]. Дослідження, проведене 3 жінками протягом 8 та 5 років 3 використанням когнітивно-біхевіоральної терапії, для жінок у віці до та після менопаузи виявило значущі вигоди в дієтичному харчуванні, вазі, об’ємі талії та частці жирової тканини в загальній масі тіла порівняно $з$ контрольною групою [13]. Одне мета-дослідження, проведене Дж. Андерсеном та співавторами [5], яке включало 29 рандомізованих контрольованих досліджень, забезпечило надійне підтвердження того положення, що втрата ваги, досягнена за допомогою когнітивнобіхевіоральної терапії тривалістю 6 місяців чи менше, мала результат у стабілізації маси тіла та попередженні подальшого набору маси тіла принаймні протягом 18 місяців після лікування.

Соціально-когнітивна теорія, яка базується на теорії соціального научіння, має в основі переконання, що люди вчаться, спостерігаючи один за одним та використовують внутрішній мисленнєвий процес, на який може впливати особистість (наприклад, переконання), оточення (наскільки воно є підтримуючим) та поведінка (наприклад, легкість завдання). Такі стратегії можуть полегшити процес навчання: научіння через спостереження, постановка поступових цілей, розбивка задачі на дрібніші елементи, тренінг розвитку вмінь. Соціально-когнітивна теорія зазвичай викори- стовується в групах. Тільки два невеликих рандомізованих контрольованих дослідження засвідчили використання соціальнокогнітивної теорії як теоретичної основи для психологічної допомоги при розладах харчової поведінки. У цих дослідженнях не вдалося показати видимий ефект [10]. Отже, необхідні додаткові рандомізовані контрольовані дослідження зі збільшеною інтенсивністю та тривалістю, щоб краще дослідити застосування цієї теорії в психологічній допомозі людям із розладами харчової поведінки.

Стратегії консультування 3 проблем розладів харчової поведінки - це емпірично обгрунтовані методи чи плани дій для досягнення поведінкових змін щодо конкретних цілей клієнта. Група експертів емпірично довела, що ефективними можуть бути такі стратегії психологічної допомоги при розладах харчової поведінки: мотиваційне опитування, самоспостереження, використання замінників їжі та/або структуровані плани харчування, стратегії заохочень, вирішення проблем, соціальна підтримка, постановка цілей, когнітивна реструктуризація, стрес-менеджмент та контроль подразників.

Мотиваційне опитування - це клієнтцентрована стратегія для поведінкових змін через допомогу клієнтам дослідити та вирішити амбівалентність стосовно змін. Використовуючи цю стратегію, слід проявляти емпатичне, незасуджуюче, підтримуюче, заохочуюче та активне слухання. Відкриті запитання, реф- 
лексивні слухання, аффірмації та узагальнення використовуються для того, щоби допомогти клієнту дослідити та вирішити амбівалентність та перешкоди до поведінкових змін.

Дослідники оцінювали ефективність мотиваційного опитування як додаткового компоненту когнітивно-біхевіоральної програми або програми самодопомоги [15]. Підтверджена статистична значущість, яка вказує, що мотиваційне опитування значно підсилило дотримання рекомендацій програми та покращило цільові результати, пов'язані із дієтою, включаючи глікемічний контроль, процентне співвідношення жирів, фруктів та овочів, та втрату маси тіла.

Самоспостереження використовується в когнітивно-біхевіоральній терапії та соціально-когнітивній теорії і припускає, що клієнт записує думки, емоції, акти харчової поведінки, фізичну активність та/або медичні вимірювання (наприклад, рівень цукру в крові, тиск). Ці записи переглядаються разом із клієнтом на предмет тригерів та патернів та використовуються, щоб допомогти 3 вирішенням проблем та постановкою цілей. Три рандомізовані контрольовані дослідження статистично значуще довели, що самоспостереження спожитої їжі покращує результати, пов'язані 3 харчуванням і призводить до втрати ваги [8]. У кількох дослідженнях було продемонстровано, що клієнти, залучені до когнітивнобіхевіоральних програм втрати ваги, які були більш наполегливі у самоспостереженні, ви- явилися значно більш успішними у втраті ваги [7].

Заміна їжі та структуровані харчові плани допомагають учасникам контролювати власне споживання їжі, фокусуючись на контролі за порціями в процесі модифікації харчових звичок. Використання замінників їжі зменшує кількість часу на міркування про вибір їжі та приготування для однієї або двох страв на день, знижує візуальні контакти з їжею, яка може спокусити учасників до переїдання та дозволяє уникнути проблем недооцінки розміру порції. У дослідженнях Ешлі та співавторів [6] однорічна біхевіоральна програма під керівництвом фахівця-психолога, яка включала заміну їжі, була значуще більш ефективною, аніж, $з$ одного боку, біхевіоральна програма без замінників їжі та, з іншого боку, індивідуальне консультування лікарем-терапевтом разом із заміною їжі.

Стратегії винагороди включають систематичний процес, в якому фахівець чи клієнт використовує винагороди за специфічні поведінкові зміни. У психологічному консультуванні 3 харчової поведінки винагороди можуть використовуватися за відвідування, заповнення щоденника харчування, втрату ваги або досягнення визначеної мети. У дослідженнях [14] було показано, що фінансові винагороди, які давалися за набуття навичок чи втрату ваги, не мали терапевтичного ефекту.

Техніки вирішення проблем часто використовуються у співпраці 3 клієнтами i 
включають ідентифікацію перешкод на шляху до досягнення мети, рішення за допомогою мозкового штурму, зважування «за» та «проти» потенційних рішень, застосування рішень, оцінка ефективності рішень та пристосування до різних стратегій. У двох рандомізованих контрольованих дослідженнях (одному - 3 жінками з надмірною вагою, а іншому - 3 жінками 3 діабетом після менопаузи) було підтверджено, що використання стратегії вирішення проблем мало результатом стабільне зниження ваги [9]. У жінок із діабетом використання стратегії вирішення проблем було пов'язане 3 покращенням показників споживання жирів, самоефективності та фізичної активності.

Соціальна підтримка може бути визначена як здатність будувати та використовувати мережу родичів, друзів, колег та фахівців (психологів та дієтологів) для інформування, заохочення, емоційної підтримки та покращення оточення для сприяння поведінковим змінам. Психологи можуть допомогти клієнтам використовувати цю стратегію через створення відносин співпраці з клієнтом, допомогу клієнту в тому, аби ідентифікувати потенційну підтримку родини та спільноти, і спрямування клієнта на ефективне використання цієї підтримки. Оцінювання ефективності соціальної підтримки для харчової поведінки широко варіює та включає множинні вимірювання соціальні підтримки, діагностовані за допомогою найрізноманітніших інструментів та критеріїв. У двох дослідженнях був оцінений ефект включення в біхевіоральну терапію друга або шлюбного партнера, але тут не було виявлено значущого терапевтичного ефекту [17]. В іншому дослідженні високоінтенсивних життєвих змін було виявлено, що соціальна підтримка допомагає опосередкувати вплив на фізичну активність та споживання жирів. Додаткові дослідження необхідні, щоб виміряти ефекти різних видів соціальної підтримки.

\section{Висновки 3 проведеного досліджен-}

ня. 3 наведеного вище можна зробити наступні висновки. Процес піклування про харчову поведінку, який включає клієнт-центровані консультативні методики, - це важливий компонент ефективного попередження та лікування хронічних хвороб. Консультування 3 проблем харчової поведінки, здійснюване фахівцями, показало здатність покращити втрату ваги, стабілізацію ваги, рівні цукру в крові для людей 3 діабетом другого типу та ризиками серцево-судинних хвороб. Дуже багато експериментальних даних підтверджують гіпотезу про те, що когнітивно-біхевіоральна терапія полегшує поведінкові зміни, націлені на зниження ризику серцево-судинних хвороб, попередження та лікування діабету та втрату ваги.

Конструкти, змінні та стратегії, які є центральними для соціально-когнітивної теоpiї (теорії соціального научіння), часто використовуються як частина дієвого консультування - наприклад, демонстрування, тренінг навичок і т.д. Численні інструменти були валі- 
дизовані для вимірювання основних понять цієї теорії (самоефективність та очікування результатів), але дуже небагато досліджень щодо консультування людей з розладами харчової поведінки з використанням цієї теоретичної моделі були опубліковані.

Переконливі емпіричні дані підтверджують ефективність само-спостереження, мотиваційного опитування (зокрема, в поєднанні 3 когнітивно-біхевіоральною терапією), заміна їжі та структуровані плани харчування як стратегії в психологічній допомозі людям 3 розладами харчової поведінки. Наявні дослідження не підтримують використання фінансових винагород як ефективної стратегії для змін у поведінці, пов'язаних із харчуванням.

\section{Перспективи подальших досліджень.}

Надійні експерииментальні дані підтверджують ефективність використання стратегій постановки цілей, вирішення проблем та соціальної підтримки, але потрібні подальші дослідження, щоб оцінити ефективність цих стратегій на більших вибірках та 3 ширшим спектром цілей, пов'язаних із контролем харчової поведінки.

\section{Перелік використаних джерел:}

1. Бек $A$. Когнитивная терапия: полное руководство / Бек А., Бек, Д.С. - М.: «Вильямс», 2006. - 486 с.

2. Хекхаузен $Х$. Мотивация и деятельность / Хекхаузен Х. - СПб.: Питер, 2003. - 860 с.

3. Хъелл Л. Теории личности (Основные положения, исследования и применение) / Хъелл Л., Зиглер Д. -
СПб.: Питер, 1999. - 608 с.

4. Тхостов А. Ш. Психология телесности / А. Ш. Тхостов. - М. : Смысл, 2002. - 287 c.

5. Anderson $J$. $W$. Long-term weight maintenance: A metaanalysis of US studies / Anderson J.W., Konz E.C., Frederich R.C., Wood C.L. // American Journal of Clinical Nutrition. - 2001, №74. - p. 579-584.

6. Ashley J. M. Weight control in the physician's office / Ashley J.M., St-Jeor S.T., Schrage J.P. Perumean-Chaney S.E., Gilbertson M.C., McCall N.L., Bovee V. // Archives of Internal Madicine. - 2001, № 161. - p. 1599-1604.

7. Baker R. C. Weight control during the holidays: Highly consistent self-monitoring as a potentially useful coping mechanism / Baker R.C., Kirschenbaum D.S. // Health Psychology. - 1998, №17. - p. 367-370.

8. Boutelle K. N. How can obese weight controllers minimize weight gain during the high risk holiday season? By self-monitoring very consistently / Boutelle K.N., Kirschenbaum D.S., Baker R.C., Mitchell M.E. // Health Psychology. - 1999, №18. - p. 364-368.

9. Glasgow R. E. Assesment of problem-solving. A key to successful diabetes management / Glasgow R.E., Toobert D.J., Barrera M., Strycker L.A. // Journal of Behavioral Medicine. - 2004, № 27. - p. 477-490.

10. Glasgow R. E. Nutrition education and social learning interventions for type II diabetes / Glasgow R.E., Toobert D.J. Mitchell D.L., Donelly J.E., Calder D. // Diabetes Care. - 1989, №12. - p. 150-152.

11. Kim S. Effects of lifestyle modification on metabolic paremeters and carotid intima-media thickness in patients with type 2 diabetes mellitus / Kim S., Lee S., Kang E., Hur K., Lee H., Ahn C., Cha B., Yoo J., Lee H. // Metabolism. 2006, № 5, p. 1053-1059.

12. Knowler $W$. C. Reduction in the incidence of type 2 diabetes with lifestyle intervention or metformin / Knowler W.C., Barret-Connor E., Fowler S.E., Hamman R.F., Lachin J.M., Walker E.A., Nathan D.M. // New English Journal of Medicine. - 2002, № 346. - p. 393-403.

13. Kuller L. H. Women's Healthy Lifestyle Project: A 
randomized clinical trial: Results at 54 months / Kuller L.H., Simkin-Silverman L.R., Wing R.R., Meilahn E.N., Ives D.G. // Circulation. - 2001, №103. - p. 32-37.

14. Paul-Ebhohimhen $V$. Systematic review of the use of financial incentives in treatments for obesity and overweight / Paul-Ebhohimhen V., Avenell A. // Obesity Reviews. -2007 , № 23. - p. 1-13.

15. Resnikow $K$. A motivational interviewing intervention to increase fruit and vegetable intake through blach churches: Results of the Eat for Life Trial / Resnikow K., Jackson A., Wang T., De A.K., McCarty F., Dudley W.N., Baranowski T. // American Journal of Public Health. - 2001, №91. - p. 1686-1692.

16. The Look AHEAD Research Group. Reduction in weight and cardiovascular disease risk factors in individuals with type 2 diabetes / The Look AHEAD Research Group // Diabetes Care. - 2000, № 30. - p. 13741383.

17. Wing R. B. Benefits of recurring participants with friends and increasing social support for weight loss and maintenance / Wing R.B., Jeffery R.W. // Journal of Consulting and Clinical Psychology - 1999, № 67. - p. 132138.

\section{References (Transliteration):}

1. Bek A. Kognitivnaya terapiya: polnoe rukovodstvo / Bek A., Bek, D.S. - M.: «Vilyams», 2006. - 486 c.

2. Hekhauzen H. Motivatsiya i deyatelnost / Hekhauzen H. - SPb.: Piter, 2003. - $860 \mathrm{~s}$.

3. H'ell L. Teorii lichnosti (Osnovnyie polozheniya, issledovaniya i primenenie) / H'ell L., Zigler D. - SPb.: Piter, 1999. - $608 \mathrm{~s}$.

4. Thostov A. Sh. Psihologiya telesnosti / A. Sh. Thostov. M. : Smyisl, 2002. - $287 \mathrm{~s}$.

5. Anderson $J$. $W$. Long-term weight maintenance: A metaanalysis of US studies / Anderson J.W., Konz E.C., Frederich R.C., Wood C.L. // American Journal of Clinical Nutrition. - 2001, №74. - p. 579-584.

6. Ashley J. M. Weight control in the physician's office /
Ashley J.M., St-Jeor S.T., Schrage J.P. Perumean-Chaney S.E., Gilbertson M.C., McCall N.L., Bovee V. // Archives of Internal Madicine. - 2001, № 161. - p. 1599-1604.

7. Baker R. C. Weight control during the holidays: Highly consistent self-monitoring as a potentially useful coping mechanism / Baker R.C., Kirschenbaum D.S. // Health Psychology. - 1998, №17. - p. 367-370.

8. Boutelle K. N. How can obese weight controllers minimize weight gain during the high risk holiday season? By self-monitoring very consistently / Boutelle K.N., Kirschenbaum D.S., Baker R.C., Mitchell M.E. // Health Psychology. - 1999, №18. - p. 364-368.

9. Glasgow R. E. Assesment of problem-solving. A key to successful diabetes management / Glasgow R.E., Toobert D.J., Barrera M., Strycker L.A. // Journal of Behavioral Medicine. - 2004, № 27. - p. 477-490.

10. Glasgow R. E. Nutrition education and social learning interventions for type II diabetes / Glasgow R.E., Toobert D.J. Mitchell D.L., Donelly J.E., Calder D. // Diabetes Care. - 1989, №12. - p. 150-152.

11. Kim S. Effects of lifestyle modification on metabolic paremeters and carotid intima-media thickness in patients with type 2 diabetes mellitus / Kim S., Lee S., Kang E., Hur K., Lee H., Ahn C., Cha B., Yoo J., Lee H. // Metabolism. 2006, № 5, p. 1053-1059.

12. Knowler $W$. C. Reduction in the incidence of type 2 diabetes with lifestyle intervention or metformin / Knowler W.C., Barret-Connor E., Fowler S.E., Hamman R.F., Lachin J.M., Walker E.A., Nathan D.M. // New English Journal of Medicine. - 2002, № 346. - p. 393-403.

13. Kuller L. H. Women's Healthy Lifestyle Project: A randomized clinical trial: Results at 54 months / Kuller L.H., Simkin-Silverman L.R., Wing R.R., Meilahn E.N., Ives D.G. // Circulation. - 2001, №103. - p. 32-37.

14. Paul-Ebhohimhen $V$. Systematic review of the use of financial incentives in treatments for obesity and overweight / Paul-Ebhohimhen V., Avenell A. // Obesity Reviews. -2007 , № 23. - p. 1-13.

15. Resnikow $K$. A motivational interviewing intervention to increase fruit and vegetable intake through blach church- 
es: Results of the Eat for Life Trial / Resnikow K., Jackson A., Wang T., De A.K., McCarty F., Dudley W.N., Baranowski T. // American Journal of Public Health. - 2001, №91. - p. 1686-1692.

16. The Look AHEAD Research Group. Reduction in weight and cardiovascular disease risk factors in individuals with type 2 diabetes / The Look AHEAD Research Group // Diabetes Care. - 2000, № 30. - p. 1374-1383.

17. Wing R. B. Benefits of recurring participants with friends and increasing social support for weight loss and maintenance / Wing R.B., Jeffery R.W. // Journal of Consulting and Clinical Psychology - 1999, № 67. - p. 132138.

\section{Absalyamova Larysa}

Candidate of psychological sciences, associate professor, associate professor at the department of practical psychology, G.S. Skovoroda National Pedagogical University, Kharkiv (Ukraine)

\section{THE EFFICACY ANALYSIS OF METHODS AND STRATEGIES OF PSYCHOLOGICAL HELP WITH FOOD BEHAVIOR DISORDERS}

\section{ABSTRACT}

Psychological help at disorders of food behavior is investigated in the article. It is viewed as a supporting process for raising of priorities and aims, and also creation of the individualized plans of action, that acknowledges and supports responsibility of the client. It is underlined that the behavioral theory and the cognitivebehavioral theory are based on supposition, that all behavior is learned, and that internal and external factors influence on personal behavior. These theories encourage such strategies, as selfmonitoring and decision of problems, that does people more attentive to the internal and external factors and reactions on these factors. Therapeutic efficiency of these theories is checked up in different empiric researches. Substantive provisions are analysed in relation to the counceling on the problems of food behavior, carried out by specialists, that has ability to improve the loss of weight, stabilizing of weight, levels of blood sugar for people with diabetes of the second type and risks of cardiovascular illnesses. Very many experimental data confirm a hypothesis that cognitivebehavioral therapy facilitates the behavioral changes, aimed at the decline of risk of cardiovascular illnesses, warning and treatment of diabetes and loss of weight. Convincing empiric data confirm efficiency of self-monitoring, motivational questioning (in particular, in combination with cognitive-behavioral therapy), replacement of meal and structured meal plans as strategies in a psychological help to the people with disorders of food behavior.

Key words: food behavior, psychological help, disorder of food behavior, cognitivebehavioral theory, cognitive-behavioral psychotherapy, strategies of counseling, self-monitoring, motivational questioning.

\section{Абсалямова Лариса Николаевна}

Кандидат психологических наук, доиент, дочент кафедры практической психологии, Национальный педагогический университет имени Г.С. Сковороды, г. Харьков (Украина)
АНАЛИЗ ЭФФЕКТИВНОСТИ МЕТОДОВ И СТРАТЕГИЙ ПСИХОЛОГИЧЕСКОЙ ПОМОЩИ ПРИ РАССТРОЙСТВАХ ПИЩЕВОГО ПОВЕДЕНИЯ 
Аннотация. В статье исследуется психологическая помощь при расстройствах пищевого поведения как поддерживающий процесс для постановки приоритетов и целей, а также создания индивидуализированных планов действия. Подчеркивается, что бихевиоральная теория и когнитивно-бихевиоральная теория основаны на предположении, что всякое поведение является научаемым, и что внутренние и внешние факторы влияют на поведение личности. Эти теории поощряют такие стратегии, как самонаблюдение и решение проблем, которое делает людей внимательнее к внутренним и внешним факторам и своим реакциям на эти факторы. Проверяется терапевтическая эффективность этих теорий в разных эмпирических исследованиях. Анализируются основные положения относительно того, что консультирование по проблемам пищевого поведения, осуществляемое специалистами, имеет способность улучшить потерю веса, стабилизацию веса, уровни сахара в крови для людей с диабетом второго типа и рисками сердечно-сосудистых болезней. Очень многие экспериментальные данные подтверждают гипотезу о том, что когнитивнобихевиоральная терапия облегчает поведенческие изменения, нацеленные на снижение риска сердечно-сосудистых болезней, предупреждение и лечение диабета, потерю веса. Убедительные эмпирические данные подтверждают эффективность самонаблюдения, мотивационного опроса (в частности, в сочетании с когнитивно-бихевиоральной терапией), замена еды и структурированные планы питания как стратегии в психологической помощи людям с расстройствами пищевого поведения.

Ключевые слова: пищевое поведение, психологическая помощь, расстройство пищевого поведения, когнитивно-бихевиоральная теория, когнитивно-бихевиоральная психотерапия, стратегии консультирования, самонаблюдение, мотивационный опрос.

Дата отримання статті: 16.10 .2017 Дата рекомендації до друку: 20.10.2017 